\title{
PENDIDIKAN KARAKTER \\ DALAM PEMBELAJARAN MATEMATIKA DI SD
}

\author{
Nuning Khamidah \\ STAIN Purwokerto \\ Jl. Jend. A. Yani Nomor 40A Purwokerto, Jawa Tengah \\ email : nuning.khamidah@yahoo.co.id
}

\begin{abstract}
Mathematics has an important role in various disciplines and advance the human intellect. Efforts to equip learners to be a master of science and technology, not enough if only concentrated on cognitive mastery. $t$ is necessary also debriefing cultivation of character education for students in question. Planting through character education in learning mathematics, students are expected to practice good science in a balanced cognitive, affective and psikomorik.
\end{abstract}

Keywords: education, character, learning, math.

\begin{abstract}
Abstrak
Matematika memiliki peran penting dalam berbagai disiplin ilmu dan memajukan daya pikir manusia. Upaya membekali peserta didik menjadi seorang yang menguasai ilmu pengetahuan dan teknologi, belum cukup apabila hanya tertumpu pada penguasaan kognitif. Hal ini diperlukan juga pembekalan penanaman pendidikan karakter bagi peserta didik yang bersangkutan. Melalui penanaman pendidikan karakter dalam pembelajaran matematika, diharapkan peserta didik dapat mengamalkan ilmu secara seimbang baik kognitif, psikomorik maupun afektif.

Kata kunci: pendidikan, karakter, pembelajaran, matematika.
\end{abstract}

\section{Pendahuluan}

Masalah pokok yang sangat menonjol dewasa ini, adalah kaburnya nilai-nilai di mata generasi muda. Hal ini dihadapkan kepada berbagai 


\section{Nuning Khamidah}

kontradiksi dan aneka ragam moral, yang menyebabkan bingung untuk memilih mana yang baik. Hal ini nampak jelas yang sedang berada pada usia remaja, terutama pada yang hidup di kota-kota besar Indonesia, yang mencoba mengembangkan diri ke arah kehidupan yang disangka maju dan modern, di mana berkecamuk aneka ragam kebudayaan asing yang masuk seolah-olah tanpa saringan (Daradjat, 2010 : 153).

Perkembangan ilmu pengetahuan dan teknologi memberi dampak perubahan bersifat positif maupun negatif. Pendidikan merupakan salah satu upaya menuntun peserta didik untuk mengambil manfaat yang positif dan menghindari yang negatif dalam perkembangan ilmu pengetahuan dan teknologi. Dengan demikian, pendidikan diharapkan dapat mengarahkan peserta didik menjadi generasi yang maju berlandaskan nilai-nilai positif.

Dalam konteks universal pendidikan karakter muncul dan berkembang awalnya dilandasi oleh pemikiran bahwa sekolah tidak hanya bertanggung jawab agar peserta didik menjadi sekedar cerdas, tetapi juga harus bertanggung jawab untuk memberdayakan dirinya agar memiliki nilai-nilai moral yang memadukannya dalam kehidupan sehari-hari. Di negara-negara Barat, di Amerika Serikat khususnya, pendidikan karakter berkembang karena dirasakan semakin lemahnya pengaruh keluarga terhadap anak-anak, dan semakin kuatnya pengaruh teman sebaya (peer), terjadi kemerosotan moral, berkembang meluasnya penyalahgunaan narkotika, seks bebas, makin ditinggalkannya nilai-nilai agama, dan semakin banyaknya kriminalitas dan kekerasan yang pelakunya anak-anak usia sekolah (Samani dan Hariyanto, 2012 : 10).

Keberhasilan dalam membangun karakter siswa akan membantu dalam membangun suatu bangsa. Oleh karena itu, kemajuan suatu bangsa juga tergantung karakter kepribadian, inovasi kertampilan, kemampuan intelegensi, serta keunggulan berpikir masyarakatnya. Dengan demikian dapat disimpulkan bahwa pendidikan karakter dapat dijadikan wahana yang penting dalam membangun moral dan kepribadian bangsa.

Pemerhati pendidikan hendaknya mampu memberikan sosialisasi yang menyeluruh terkait dengan pendidikan karakter. Nilai-nilai yang terdapat pada setiap mata pelajaran memberikan arahan kepada pendidik dan peserta didik dalam mengaplikasikan pendidikan karakter. Kegiatan integrasi pendidikan karakter dengan mata pelajaran matematika diharapkan 
dapat memberikan kesan dalam pembelajaran matematika tentu memiliki nilai yang belum disadari dapat membentuk karakter peserta didik.

Hal yang paling penting di sini adalah bahwa pada rencana nasional dalam implementasi pendidikan karakter telah ditetapkan ada mata pelajaran yang berdampak pembelajaran (intructional effect) sekaligus dampak pengiring (nurturant effect), juga ada mata pelajaran yang hanya memiliki dampak pengiring. Mata pelajaran yang disepakati memiliki dampak keduanya adalah Pendidikan Agama dan Pendidikan Kewarganegaraan (Samani dan Hariyanto, 2012 : 176). Semua mata pelajaran bertanggung jawab terhadap penanaman nilai keimanan dan ketakwaan serta akhlak mulia. Jika demikian, maka seharusnya semua mata pelajaran harus dapat disisipkan dengan penanaman nilai Imtaq dan akhlak mulia, termasuk diantaranya mata pelajaran matematika.

Pada tahun-tahun terakhir ini, prosedur matematika dan materi matematika lebih banyak digunakan dalam berbagai cabang ilmu, seperti fisika, kimia, biologi, kedokteran, ekonomi, dan teknik. Penggunaan matematika yang semakin meningkat menunjukkan bahwa peran matematika di dalam kehidupan umat manusia pada "abad teknologi" ini sangat mutlak (saputro, $1992: 21)$.

Matematika memiliki peran penting dalam berbagai disiplin ilmu dan memajukan daya pikir manusia. Upaya membekali peserta didik menjadi seorang yang menguasai ilmu pengetahuan dan teknologi, belum cukup apabila hanya tertumpu pada penguasaan kognitif. Hal ini diperlukan juga pembekalan penanaman pendidikan karakter bagi peserta didik yang bersangkutan. Melalui penanaman pendidikan karakter dalam pembelajaran matematika, diharapkan peserta didik dapat mengamalkan ilmu secara seimbang baik kognitif, psikomorik maupun afektif.

Matematikamerupakanilmuuniversal yangmendasariperkembangan teknologi modern, mempunyai peran penting dalam berbagai disiplin dan memajukan daya pikir manusia. Perkembangan pesat di bidang teknologi informasi dan komunikasi dewasa ini dilandasi oleh perkembangan matematika di bidang teori bilangan, aljabar, analisis, teori peluang, dan matematika diskrit. Untuk menguasai dan mencipta teknologi di masa depan diperlukan penguasaan matematika yang kuat sejak dini (Ibrahim dan Suparni, $2012: 35$ ). 
Mata pelajaran matematika perlu diberikan kepada semua peserta didik mulai dari sekolah dasar tentu memiliki tujuan, antara lain yaitu untuk membekali peserta didik dengan kemampuan berpikir logis, analitis, sistematis, kritis, dan kreatif, serta kemampuan bekerjasama. Kompetensi tersebut diperlukan agar peserta didik dapat memiliki kemampuan memperoleh, mengelola, dan memanfaatkan informasi.

Pada bulan April tahun 2000, National Council of Teachers of mathematics (NCTM) mengeluarkan Prinsip-Prinsip dan Standar Matematika Sekolah (Principles and Standars for School Mathematics), yang merupakan dari dokuman aslinya yang dikeluarkan 11 tahun sebelumnya pada tahun 1989. Dengan dokumen ini NCTM melanjutkan untuk mengarahkan perubahan dalam bidang pendidikan matematika, tidak hanya di Amerika Serikat dan Kanada tetapi juga di seluruh dunia (Walle, $2006: 1-2$ ).

Perhatian terhadap perkembangan kurikulum matematika tahun terakhirdibanyaknegara di dunia ini menunjukkan bahwa sistem pendidikan matematika perlu disesuaikan sesuai kebutuhan peserta didik. Kebutuhan di masa kini terus berkembang yang dipengaruh oleh ilmu pengetahuan dan teknologi. Kecenderungan semacam itu memerlukan akumulasi pengetahuan dan kemampuan yanng lebih besar. Sehingga peserta didik diharapkan mampu menyesuaikan dirinya terhadap perubahan-perubahan maupun masalah-masalah yang dihadapi.

Setiap guru matematika perlu memahami akan pentingnya motivasi yang sesuai dalam proses belajar mengajar. Peserta didik yang kurang minat mempelajari matematika, perlu diberi rangsangan melalui teknik dan cara pengajaran yang tepat agar senang mempelajari. Hanya dengan cara yang demikian dapat menghilangkan masalah-masalah seperti kegelisahan terhadap matematika, yang merupakan masalah umum bertahun-tahun.

Menurut Bruner sebagaimana dikutip oleh Ruseffendi, dalam metode penemuannya mengungkapkan bahwa dalam pembelajaran matematika siswa harus menemukan sendiri berbagai pengetahuan yang diperlukan. "menemukan" di sini terutama adalah "menemukan lagi' (discovery), atau dapat juga menemukan yang sama sekali baru (invention). Oleh karena itu, kepada siswa matematika disajikan bukan dalam bentuk akhir dan tidak diberitahukan cara penyelesaiannya. Dalam pembelajaran ini, guru harus lebih banyak berperan sebagai pembimbing dibandingkan sebagai 
pemberitahu (Heruman, 2008 :4). Proses pembelajaran matematika diharapkan sebagai wahana untuk pembentukan karakter peserta didik. Nilai-nilai pendidikan karakter secara tidak langsung benar-benar tertanam dalam pembelajaran tersebut.

Nilai-nilai pendidikan karakter dalam pembelajaran matematika dapat berupa kemampuan memecahkan berbagai problem yang ada dalam kehidupan sehari-hari. Dalam pembelajaran matematika, peserta didik diharapkan mampu mengamalkan nilai-nilai tersebut tidak hanya pada saat pelaksanaan kegiatan belajar di kelas, melainkan dapat diterapkan dalam kehidupan dirinya sendiri. Hal ini bertujuan peserta didik memiliki pemikiran kritis, sistematis, logis dan kreatif, dan kemampuan bekerjasama yang efektif. Cara berpikir seperti ini dapat dikembangkan melalui belajar matematika karena matematika memiliki struktur dan keterkaitan yang kuat dan jelas antar konsepnya, sehingga memungkinkan siswa berpikir rasional. Nilai yang telah disebutkan di atas pada saat ini marak dikenal sebagai konsep pendidikan karakter. SD Insan Teladan merupakan lembaga pendidikan dasar yang menerapkan konsep pendidikan karakter.

SD Insan Teladan beralamat di Desa Kalisuren, Kecamatan Tajurhalang, Kabupaten Bogor Jawa Barat. Sekolah ini didirikan oleh Institute of Sathya Sai Education Indonesia (ISSEI) dan Yayasan Nur Ilahi pada tahun 2004. Di sekolah ini, pendidikan karakter diimplementasikan melalui Pendidikan Nilai-Nilai Kemanusiaan (PNK) yang dibagi menjadi lima nilai utama, yaitu kebenaran, kebajikan, kedamaian, cinta kasih, dan berperilaku tanpa kekerasan. Nilai-nilai ini dianut oleh seluruh warga sekolah, dimulai dari para pendiri, pemangku kepentingan, guru, siswa, dan seluruh orangtua (Samani dan Hariyanto, 2012 : 227-228).

Berdasarkan wawancara pada saat observasi pendahuluan kepada kepala sekolah yakni Ibu Indra Sari, bahwa pembelajaran matematika dilaksanakan berdasarkan nilai-nilai pendidikan karakter yang termaktub dalam Rencana Pelaksanaan Pembelajaran. Misalkan dalam pembelajaran matematika berdasarkan materi bilangan menunjukkan bahwa siswa dapat berbagi dengan sesama melalui cara pembagian angka-angka yang dimaksud. Beliau menambahkan pula, dalam menerapkan pendidikan karakter tidak semudah membalikkan telapak tangan. Hal ini perlu ada kerjasama yang mendukung dari berbagai aspek guna tercapainya kese- 


\section{Nuning Khamidah}

larasan dalam menerapkan pendidikan karakter di sekolah ini. Mengacu pada penjelasan tersebut, serta reaita di lapangan dan diperkuat oleh teori yang ada, maka peneliti tertarik mengamati, mengkaji, dan menganalisis lebih dalam terkait dengan pendidikan karakter dalam pembelajaran matematika di SD Insan Teladan Desa Kalisuren, Kecamatan Tajurhalang, Kabupaten Bogor, Jawa Barat.

Dari sinilah muncul pemikiran penulis bahwa pembelajaran matematika dapat dijadikan sebagai wahana dalam menanamkan nilainilai pendidikan karakter. Oleh karena itu perlu adanya pengamatan yang mendalam dan analisis yang tajam terkait dengan kegiatan belajar mengajar pelajaran matematika yang terintegrasikan dengan nilai-nilai pendidikan karakter di sekolah yang bersangkutan.

\section{Pendidikan Karakter}

Pendidikan karakter adalah usaha sadar dan terencana untuk mewujudkan suasana serta proses pemberdayaan potensi dan pembudayaan peserta didik guna membangun karakter pribadi dan atau kelompok yang unik-baik sebagai warga negara. Hal itu diharapkan mampu memberikan kontribusi optimal dalam mewujudkan masyarakat yang berketuhanan Yang Maha Esa, berkemanusiaan yang adil dan beradab, berjiwa persatuan Indonesia, berjiwa kerakyatan yang dipimpin oleh hikmat kebijaksanaan dalam permusyawaratan perwakilan, berkeadilan sosial bagi seluruh rakyat Indonesia

Pendidikan karakter memiliki peran penting dalam pelaksanaan pembelajaran di sekolah. Adanya kebiasaan yang membuat peserta didik memiliki sikap-sikap nilai yang bersangkutan sangat memberikan dampak positif dalam pembentukan pribadinya. Melalui penanaman pendidikan karakter di sekolah, dapat memberikan kontribusi tersendiri bagi peserta didik dalam pembentukan karakternya.

Pendidikan karakter dalam setting sekolah didefinisikan sebagai proses pembelajaran yang mengarah pada penguatan ddan pengembangan perilaku anak secara utuh yang didasarkan pada suatu nilai tertentu yang dirujuk oleh sekolah. Menurut Tim Penelitian Program DPP Bidang Minat Bakat \& Ketrampilan Fakultas Tarbiyah dan Keguruan UIN Sunan Kalijaga Yogyakarta (2011 : 8) definisi ini mengandung makna : 
1. Pendidikan karakter merupakan pendidikan yang terintegrasikan dengan pembelajaran yang terjadi pada semua mata pelajaran.

2. Diarahkan pada penguatan dan pengembangan perilaku anak secara utuh. Asumsinya anak merupakan organisme manusia yang memiliki potensi untuk dikuatkan dan dikembangkan.

3. Penguatan dan pengembangan perilaku didasari oleh nilai yang dirujuk sekolah atau lembaga.

Berdasarkan pembahasan di atas dapat ditegaskan bahwa pendidikan karakter merupakan upaya-upaya praktisi pendidikan yang dirancang dan dilaksanakan secara sistematis untuk membantu peserta didik memahami nilai-nilai perilaku manusia yang berhubungan dengan Tuhan Yang Maha Esa, diri sendiri, sesama manusia, lingkungan, dan kebangsaan yang terwujud dalam pikiran, sikap, perasaan, perkataan, dan perbuatan berdasarkan norma-norma agama, hukum, tata krama, budaya, dan adat istiadat.

\section{Pembelajaran Matematika}

Pembelajaran Matematika adalah proses pemberian pengalaman belajar kepada siswa melalui serangkaian kegiatan yang terencana sehingga siswa memperoleh kompetensi tentang bahan matematika yang dipelajari (http://lenterakecil.com/pembelajaran-matematika-di-sekolah-dasar/).

Dengan demikian pembelajaran matematika merupakan kegiatan yang mengarahkan kepada peserta didik dalam mempelajari esensi dari pemecahan masalah. Matematika memiliki peran penting dalam berbagai disiplin ilmu dan memajukan daya pikir manusia. Upaya membekali peserta didik menjadi seorang yang menguasai ilmu pengetahuan dan teknologi, belum cukup apabila hanya tertumpu pada penguasaan kognitif. Hal ini diperlukan juga pembekalan penanaman pendidikan karakter bagi peserta didik yang bersangkutan. Melalui penanaman pendidikan karakter dalam pembelajaran matematika, diharapkan peserta didik dapat mengamalkan ilmu secara seimbang baik kognitif, psikomotorik maupun afektif.

Mata pelajaran matematika bertujuan agar peserta didik memiliki kemampuan sebagai berikut :

1. Memahami konsep matematika, menjelaskan keterkaitan antarkonsep dan mengaplikasikan konsep atau algoritma, secara luwes, akurat, efisien, dan tepat, dalam pemecahan masalah. 
2. Menggunakan penalaran pada pola dan sifat, melakukan manipulasi matematika dalam membuat generalisasi, menyusun bukti, atau menjelaskan gagasan dan pernyataan matematika.

3. Memecahkan masalah yang meliputi kemampuan memahami masalah, merancang model matematika, menyelesaikan model dan menafsirkan solusi yang diperoleh.

4. Mengomunikasikan gagasan dengan simbol, tabel, diagram, atau media lain untuk memperjelas keadaan atau masalah.

5. Memiliki sikap menghargai kegunaan matematika dalam kehidupan, yaitu memiliki rasa ingin tahu, perhatian, dan minat dalam mempelajari matematika, serta sikap ulet dan percaya diri dalam pemecahan masalah.

Strategi yang dilakukan guru dalam pembelajaran matematika sebaiknya disesuaikan dengan kondisi peserta didik dalam berbagai aspek. Strategi yang diterapkan dilakukan guna menjadikan kegiatan belajar metematika menjadi menyenangkan. Dengan demikian diharapkan dalam belajar matematika mereka lebih kompeten dan lebih bermakna.

\section{Metode Penelitian}

Jenis penelitian ini adalah penelitian lapangan (field research). Adapun pendekatan dalam penelitian ini menggunakan pendekatan kualitatif. Penggunaan penelitian kualitatif ini juga bertujuan supaya data-data yang diperoleh mendalam sesuai dengan makna dan fakta lapangan.

Melalui penelitian ini, peneliti lebih membutuhkan pengalaman pengamatan dan catatan lapangan yang tertumpu pada wawancara. Selain itu juga mengumpulkan dokumentasi yang sangat diperlukan guna menunjang perolehan data penelitian yang dilaksanakan di SD Insan Teladan Desa Kalisuren, Kecamatan Tajurhalang, Kabupaten Bogor Jawa Barat.

Berdasarkan penelitian yang dilakukan, maka subjek penelitian ini berdasarkan wawancara dengan Kepala Yayasan Nur Ilahi, Kepala Sekolah Dasar Insan Teladan, Guru Matematika Kelas 4 SD Insan Teladan, Guru Pendidikan Nilai-Nilai Kemanusiaan Insan Teladan, Wali Peserta didik Yayasan Nur Ilahi, dan Siswa Kelas 4 SD Insan Teladan.

Adapun teknik analisis data yang digunakan dalam penelitian ini yakni dengan analisis kualitatif. Aktivitas dalam analisis data kualitatifyaitu data reduction, data display, dan conclucion drawing atau verivication. 


\section{Hasil Penelitian dan Pembahasan}

Konsep dasar pendidikan karakter yang sudah berjalan di SD Insan Teladan adalah Pendidikan Nilai-Nilai Kemanusiaan (PNK). Adapun Pendidikan Nilai-Nilai Kemanusiaan (PNK) yang diterapkan di SD Insan Teladan dibagi menjadi lima nilai utama, yaitu kebenaran, kebajikan, kedamaian, cinta kasih, dan berperilaku tanpa kekerasan. Nilai-nilai ini dianut oleh seluruh warga sekolah, dimulai dari para pendiri, pemangku kepentingan, guru, siswa, dan seluruh orangtua.

Berdasarkan wawancara kepada Ibu Diana Safitri selaku guru bidang Studi Pendidikan Nilai-Nilai Kemanusiaan (PNK) yakni dikatakan bahwa kegiatan yang utama dalam pendidikan karakter Insan Teladan adalah Duduk Hening, Bercerita, Kegiatan Berkelompok, Bernyanyi, dan Kata Mutiara.

Berdasarkan wawancara kepada Ibu Misnia Dwi Juniantika selaku guru bidang studi Matematika kelas 3, 4, dan 5, bahwa penerapan pendidikan karakter dalam pembelajaran matematika di kelas 4 dilakukan melalui penyisipan terhadap Pendidikan Nilai-Nilai Kemanusiaan (PNK). Indikator Pendidikan Nilai-Nilai Kemanusiaan (PNK) meliputi kebenaran, kebajikan, kedamaian, cinta kasih, dan tanpa kekerasan. Adapun Pendidikan Nilai-Nilai Kemanusiaan (PNK) yang diprioritaskan dalam proses pembelajaran matematika adalah kebenaran. Adapun indikator yang termasuk nilai kebenaran tersebut yakni ketika mengerjakan soal dengan teliti serta memakai cara sebagai jalan keluar dari pemecahan masalah. Strategi yang dilakukan dalam penerapan pendidikan karakter dalam pembelajaran matematika di kelas 4 dapat melalui menyisipkan nilai-nilai kemanusian dalam proses belajar. Menyisipkan yang dimaksud adalah ketika peserta didik belajar matematika misalkan setelah selesai belajar mereka diberi kesempatan untuk mengungkapkan nilai-nilai yang terkandung dalam tema pembelajaran yang telah disampaikan. Model pembelajaran yang dilakukan pada saat pelajaran matematika variasi sesuai dengan kebutuhan. Penerapan pendidikan karakter dalam pembelajaran matematika juga dapat dilaksanakan melalui diskusi kerja kelompok. Melalui diskusi kelompok, mereka dapat berusaha untuk mampu bekerjasama dengan baik. Adapun nilai yang dominan dilaksanakan dalam pembelajaran matematika adalah Kebenaran, dan Kasih Sayang. Kebenaran dilakukan pada saat 
mengidentifikasi pemecahan soal, sedangkan kasih sayang dilaksanakan pada saat mereka melakukan kegiatan diskusi kelompok.

Berdasarkan wawancara kepada Ibu Misnia Dwi Juniantika selaku guru bidang studi Matematika kelas 3, 4, dan 5, bahwa lebih lanjut dikatakan pada saat pembelajaran matematika tidak memperbolehkan peserta didik memakai alat bantu seperti kalkulator, karena dirasa masih terlalu dini dalam pemakaian dan konsep-konsep yang diajarkan masih sederhana. Dalam memberikan pemahaman dalam pembelajaran matematika sangat memperhatikan kondisi peserta didik terutama dari segi kemampuan menangkap pelajaran. Peserta didik yang kurang mampu dalam pemecahan suatu soal maka mereka mendapat bimbingan khusus dalam belajar, sehingga mereka dapat mencerna pelajaran tersebut. Adapun evaluasi pendidikan Karakter dalam pembelajaran Matematika dilakukan berdasarkan kegiatan pada saat pembelajaran dengan melihat hasil dan proses kegiatan belajar berdasarkan tingkahlaku peserta didik dalam mengerjakan soal. Berdasarkan pemaparan dokumen terkait dengan nilai karakter dalam pembahasan sebelumnya, penulis menyimpulkan bahwa nilai-nilai karakter yang diterapkan di SD Insan Teladan telah dimasukkan dalam perangkat mengajar. Konsep Pendidikan Nilai-Nilai Kemanusiaan (PNK) tersebut digunakan sebagai media yang mengingatkan guru untuk menyampaikan nilai-nilai dibalik materi yang disampaikan. Dengan demikian karakter yang diharapkan akan mengena pada diri peserta didik. Adapun nilai yang dominan dilaksanakan dalam pembelajaran matematika adalah Kebenaran, dan Kasih Sayang. Kebenaran dilakukan pada saat mengidentifikasi pemecahan soal, sedangkan kasih sayang dilaksanakan pada saat mereka melakukan kegiatan diskusi kelompok.

Metode penyampaian Pendidikan Nilai-Nilai Kemanusiaan (PNK) kepada peserta didik dalam pembelajaran matematika yakni melalui Duduk Hening, Berdo'a, Bercerita, Bernyanyi Bersama, dan Kegiatan Berkelompok.

\section{Silent Sitting (Duduk Hening)}

Latihan konsentrasi cahaya menjadikan anak lebih fokus dalam melakukan kegiatan pembelajaran matematika. Efek dari latihan konsentrasi cahaya adalah pikiran lebih rileks, tenang dan konsentrasi 
menjadi lebih tajam. Dengan demikian, kegiatan duduk hening setiap pagi memberikan dampak positif pada peserta didik dalam memaknai kegiatan pembelajaran matematika.

2. Prayers or Dynamic Thought (Berdo'a atau Pikiran Dinamis)

Do'a yang dilakukan secara sungguh-sungguh dapat dijadikan sebagai fondasi dari keseluruhan bangunan dalam proses belajar mengajar. Ketika bel terakhir juga dilakukan kegiatan do'a bersama agar segala kegiatan belajar yang dilakukan dapat bermanfaat. Berdo'a diharapkan dapat membuat peserta didik lebih ingat kepada Tuhan. Memiliki pikiran yang jernih sehingga yakin akan kebenaran. Berdo'a setiap awal pembelajaran dan akhir pembelajaran memberikan dampak positif pada peserta didik dalam kegiatan pembelajaran matematika.

3. Story Telling (Bercerita)

Mengajarkan ceritera-ceritera yang kurang bermakna memberi dampak yang kurang baik bagi perkembangan peserta didik. Dapat dianalogikan seperti cerita kuda terbang. Sedangkan yang anak ketahui bahwa kuda memiliki empat kaki untuk berjalan. Seekor kuda memiliki empat kaki adalah suatu kenyataan yang tidak perlu diajarkan kepada peserta didik. Dalam hal ini peserta didik bisa mengetahuinya dalam waktu yang singkat.

Soal-soal tentang pembagian dan perkalian dapat digunakan dalam cerita-cerita pendek yang mengikutsertakan nilai-nilai kemanusiaan semudah yang terlihat dalam contoh di bawah ini:

Anne, Mary, dan John adalah tiga sekawan. Anne sendiri bisa mengangkat berat $10 \mathrm{~kg}$. Mary lebih kuat dari Anne, dia bisa mengangkat berat $15 \mathrm{~kg}$. John yang paling kuat, bisa mengangkat berat $20 \mathrm{~kg}$. Jika mereka bersatu dan saling membantu mengangkat beban, berapa berat yang mereka dapat angkat bersamasama? Sekarang Anne, Mary, John telah memasukkan nilai-nilai persatuan, bekerja sama dan saling menolong. Dengan bersatu mereka dapat mencapai hasil yang lebih besar.

4. Group Singing (Bernyanyi Bersama)

Bernyanyi adalah kegiatan yang menyenangkan siswa. Oleh karena itu perlu dibuatkan lagu-lagu dengan lirik yang syarat dengan pesan moral tetapi mudah dicerna. Lewat lagu-lagu peserta didik akan mengenang nilai-nilai yang terkandung dalam pesan syair tersebut. 


\section{Group Activities (Kegiatan Berkelompok)}

Kegiatan berkelompok dilakukan pada saat proses belajar mengajar matematika. Pokok bahasan yang dipelajari dengan sendirimya sudah mengandung nilai-nilai kemanusiaan sebagai sifat bawaannya. Nilainilai ini meski diungkapkan sendiri oleh peserta didik.

Pelaksanaan pendidikan karakter di SD Insan Teladan memberikan implikasi yang berarti dari berbagai kalangan. Hal ini memberikan dampak positif bagi peserta didik dalam pelaksanaan pembelajaran. Berdasarkan pengamatan dari penulis bahwa adanya pendidikan karakter menjadikan peserta didik dalam pelaksanaan ujian tidak ada yang mencontek. Pada saat pelaksanaan ujian, peserta didik dengan tenang mengerjakan soal sendirisendiri sesuai dengan kemampuan. Peserta didik telah melaksanakan Pendidikan Nilai-Nilai Kemanusiaan dengan baik maka dampaknya mereka mampu mandiri dalam memecahkan masalah dalam kehidupan sehari-hari.

Pada saat pembelajaran matematika di SD Insan Teladan tidak memperbolehkan peserta didik memakai alat bantu seperti kalkulator, karena dirasa masih terlalu dini dalam pemakaian dan konsep-konsep yang diajarkan masih sederhana. Dalam memberikan pemahaman dalam pembelajaran matematika sangat memperhatikan kondisi peserta didik terutama dari segi kemampuan menangkap pelajaran. Peserta didik yang kurang mampu dalam pemecahan suatu soal maka mereka mendapat bimbingan khusus dalam belajar, sehingga mereka dapat mencerna pelajaran tersebut. Adapun evaluasi pendidikan Karakter dalam pembelajaran Matematika dilakukan berdasarkan kegiatan pada saat pembelajaran dengan melihat hasil dan proses kegiatan belajar berdasarkan tingkahlaku peserta didik dalam mengerjakan soal.

Menurut Ibu Novi, orangtua dari Leoni (siswa kelas 7 alumni SD Insan Teladan) dan Aulia Faradiba (siswa kelas 5 SD Insan Teladan), mengemukakan: "Saya menyekolahkan anak saya di sini itu pindahan dari kota Depok. Saya benar-benar merasakan perbedaan yang terjadi pada pola belajar dan tingkahlaku anak saya sesudah belajar di SD Insan Teladan. Di SD Insan Teladan berasa sekali kekeluargaannya dan selalu memberikan motivasi positif pada anak saya sehingga mereka dapat belajar dengan giat. Dalam belajar matematika di rumah anak saya tidak pernah mengeluh, hal ini dikarenakan saya pernah menjadi guru matematika jika ada konsep- 
konsep yang belum diketahui maka saya mengarahkan anak saya dalam pemecahan masalah."

Berdasarkan pemaparan wawancara dengan orangtua tersebut dapat disimpulkan bahwa dampak penerapan Pendidikan Karakter dalam Pembelajaran Matematika di SD Insan Teladan pada peserta didik pada saat di rumah dan lingkungan sekitar adalah mampu mengaplikasikan nilainilai yang diajarkan guru pada saat pembelajaran. Dalam hal ini peserta didik lebih mengetahui tentang sikap yang harus dilakukan pada saat menjadi pelajar. Pembelajaran matematika yang dilaksanakan di sekolah sangat mengubah sikap anak pada saat belajar di rumah. Anak-anak mampu memecahkan masalah dengan penuh ketelitian dan kesabaran ketika diberi tugas dari sekolah. Dengan demikian penerapan pendidikan karakter di SD Insan Teladan memberi dampak yang positif bagi perkembangan karakter peserta didik.

Berikut hasil wawancara penulis kepada Siswa Kelas 4 SD Insan Teladan pada tanggal 14 Desember 2012 di teras depan kantor SD Insan Teladan. Amanda, bertempat tinggal di Perumahan Inkopad. Putri bertempat tinggal di seberang jalan depan sekolah. Diva, Silvi, Clara, Tiana dan Julia bertempat tinggal di belakang sekolah. Mereka senang sekali sekolah di Insan Teladan. Gurunya baik-baik, temannya baik-baik, pokoknya senang deh sekolah di sini. Tentang belajar matematika di kelas Ibu Nia baik sekali. Mau mengajari jika belum paham. Tapi kadang Ibu Nia galak jika kita tidak memperhatikan apa yang disampaikan atau kita bicara sendiri. Pelajaran matematika menurut kami sangat menyenangkan. Macem-macem kegiatan belajarnya sehingga kami tidak bosan. Bahkan Ibu Nia punya banyak media jadi belajar matematikanya tidak harus menyelesaikan soal terus, tapi ada selingan belajar matematika sambil bermain. Hal ini memberikan kami senang belajar matematika dengan Ibu Nia. Dalam belajar matematika kami tidak boleh memakai kalkulator. Pada saat ujian kami tidak ada yang mencontek. Dalam belajar matematika kami tidak di beda-bedakan dari segi suku, agama, status sosial dan lain sebagainya. Kami tetap belajar matematika bersama-sama dengan Ibu Nia.

Berdasarkan pemaparan wawancara dengan peserta didik dapat disimpulkan bahwa dampak penerapan Pendidikan Karakter dalam Pembelajaran Matematika di SD Insan Teladan pada peserta didik adalah 
mampu mengaplikasikan nilai-nilai yang diajarkan guru pada saat pembelajaran. Dalam hal ini peserta didik lebih mengetahui tentang sikap yang harus dilakukan pada saat menjadi pelajar. Pendidikan Karakter dalam Pembelajaran matematika yang dilaksanakan di sekolah menjadi simbol bahwa pemahaman pembelajaran matematika tidak hanya terpadu pada ketrampilan berfikir, akan tetapi melalui pembelajaran matematika dapat memunculkan kembali pesan nilai-nilai yang belum terlihat nyata dalam penerapan sehari-hari. Dengan demikian penerapan pendidikan karakter di SD Insan Teladan memberi dampak yang positif bagi perkembangan karakter peserta didik.

Hasil pembahasan dalam penelitian ini diharapkan dapat memberikan kontribusi pada lembaga pendidikan Madrasah Ibidaiyah sehingga karakter pada peserta didik lebih mengena. Dengan melandaskan ajaran agama Islam dalam pembelajaran di Madrasah Ibtidaiyah, maka peserta didik lebih memaknai hakikat kebenaran akan adanya Tuhan Yang Maha Esa, melakukan perbuatan yang berlandaskan nilai kebajikan bagi orang lain, mampu memberikan kedamaian kepada sesama penganut agama Islam dan non agama Islam, memiliki rasa cinta kasih kepada Allah SWT, kepada sesama manusia, dan kepada alam berserta isinya, dan berperilaku tanpa kekerasan dalam menyikapi perbedaan suku, ras, agama maupun perbedaan yang lain.

Guna mencapai pertumbuhanan integral dalam pendidikan karakter, perlu dipertimbangkan dalam memilih metode penerapan. Metode ini bisa menjadi unsur yang sangat urgen dalam penerapan pendidikan karakter di Madrasah Ibtidaiyah. Melalui metode yang sesuai dengan tataran pendidikan tingkat dasar dapat memberikan pelaksanaan pembelajaran menjadi efektif dan efisien.

Pendidikan nilai kemanusiaan jika diterapkan di Madrasah Ibtidaiyah dapat dilakukan sesuai dengan pembelajaran pendidikan agama Islam yang telah dipelajari. Metode penyampaian Pendidikan Nilai-Nilai Kemanusiaan (PNK) yang dilakukan di SD Insan Teladan kepada peserta didik seperti Duduk Hening, Berdo'a, Bercerita, Bernyanyi Bersama, dan Kegiatan Berkelompok dapat ditawarkan kegiatan yang lain sesuai dengan pembelajaran Pendidikan Agama Islam di Madrasah Ibtidaiyah. Misalkan kegiatan duduk hening bisa dilakukan dengan membaca dzikir setiap pagi 
bersama-sama. Selanjutnya berdo'a bisa diajarkan dengan membaca do'a belajar dan do'a-do'a pendek lainnya. Metode bercerita dapat disampaikan melalui kisah 25 Nabi maupun tokoh-tokoh pejuang Islam lainnya. Bernyanyi bersama bisa disampaikan cara yang lain misalkan dengan membaca Asma'ul Husna maupun dengan lagu-lagu anak-anak Islami. Kegiatan Berkelompok bisa dilaksanakan dengan menunaikan shalat Dhuha dan shalat Dzuhur serta shalat Jum'at (khusus pada hari Jum'at) secara berjama'ah.

\section{Penutup}

Berdasarkan penelitian yang dilakukan penulis, dapat diambil kesimpulan sebagai berikut :

1. Pendidikan Karakter dalam Pembelajaran Matematika di SD Insan Teladan Desa Kalisuren Kecamatan Tajurhalang Kabupaten Bogor Jawa Barat diterapkan melalui konsep Pendidikan Nilai-Nilai Kemanusiaan (PNK). Indikator dari Pendidikan Nilai-Nilai Kemanusiaan (PNK) yang dibagi menjadi lima utama, yaitu kebenaran, kebajikan, kedamaian, cinta kasih, dan berperilaku tanpa kekerasan. Nilai yang dominan dalam penerapan pendidikan karakter dalam pembelajaran matematika adalah kebenaran dan kasih sayang. Metode penyampaian Pendidikan Nilai-Nilai Kemanusiaan (PNK) kepada peserta didik yakni melalui Duduk Hening, Berdo'a, Bercerita, Bernyanyi Bersama, dan Kegiatan Berkelompok.

2. Implikasi dari pembelajaran matematika berbasis pendidikan karakter adalah menjadikan peserta didik lebih mandiri dalam belajar matematika. Mampu memecahkan masalah dalam kehidupan sehari-hari serta menjadikan peserta didik yakin akan kebenaran.

3. Kontribusi hasil penelitian pada Lembaga Madrasah Ibtidaiyah yakni penerapan Pendidikan Karakter Berbasis Pendidikan Agama Islam, serta Integrasi Pendidikan Karakter dalam Pembelajaran Matematika di Madrasah Ibtidaiyah dengan Pembelajaran Agama Islam. 


\section{Daftar Pustaka}

Amirul Hadi \& Haryono, Metodologi Penelitian Pendidikan 2, Bandung: Pustaka Setia, 1998.

Art-ong Jumsai Na Ayudhya, Integrasi Nilai-Nilai Kemanusiaan dalam Matematika dan Ilmu Pengetahuan, Alih Bahasa: Yukti Burhan, Jakarta: Komite Penerbitan Buku, Yayasan Sri Sathya Sai Indonesia, 1999.

Heruman, Model Pembelajaran Matemaika di Sekolah Dasar, Bandung: RemajaRosda Karya, 2008.

Ibrahim \& Suparni, Pembelajaran Matematika Teori dan Aplikasinya, Yogyakarta: Suka-Press, 2012.

John A. Van de Walle, Matematika Sekolah Dasar dan Menengah, alih bahasa: Suyono, Jakarta: Erlangga, 2006.

Kebijakan Nasional Pembangunan Karakter Bangsa 2010-2025, Pemerintah Republik Indonesia, 2010.

Muchlas Samani \& Hariyanto, Konsep dan Model Pendidikan Karakter, Bandung: Remaja Rosdakarya, 2012.

Saifuddin Azwar, Metode Penelitian, Yogyakarta: Pustaka Pelajar, 2012.

Standar Isi untuk Satuan Pendidikan Dasar dan Menengah, Standar Kompetensi dan Kompetensi Dasar SD/ MI, Jakarta: Badan Standar Nasional Pendidkan, 2006.

Sugiyono, Metode Penelitian Pendidikan (Pendekatan Kuantitatif, Kualitatif, dan R\&D), Bandung: Alfabeta, 2008.

Theresia M. H Tirta Saputro, Pengantar Dasar Matematika: Logika dan Teori Himpunan, Jakarta: Erlangga, 1992.

Tim Penelitian Program DPP Bidang Minat Bakat \& Ketrampilan Fakultas Tarbiyah dan Keguruan UIN Sunan Kalijaga Yogyakarta, Pendidikan Karakter: Pengalaman Implementasi Pendidikan Karakter di Sekolah, Yogyakarta: Aura Pustaka, 2011.

Zakiah Daradjat, Ilmu Jiwa Agama, Jakarta: Bulan Bintang, 2010.

http://lenterakecil.com/pembelajaran-matematika-di-sekolah-dasar/ diakses tanggal 26 Nopember 2012.

http://tiriztea.wordpress.com/2010/08/18/7-tokoh-ilmuwan-matematikaislam/ diakses tanggal 12 januari 2013. 